\title{
MODERN INFORMATION TECHNOLOGIES AND SERVICES IN PUBLIC INSTITUTIONS
}

\author{
IRYNA PIATNYCHUK, HALYNA PYATNYCHUK
}

\begin{abstract}
The article considers the issues of modern information technologies and services in public institutions (on the example of educational institutions). The aim of the article is to study the application of modern information technologies and services, in particular Google services, in such public institutions as educational institutions during the pandemic and to identify opportunities for their wider use. Based on a study to assess the economic benefits of using Google services, it has been found that their wider use in educational institutions will also have a positive effect. It is determined that the use of the service "Google" allows you to solve problems of information support of management and educational processes in the educational institution, work together on different types of documents, avoid distortion of information while working on them by different users by setting the appropriate level of document access. Based on the study, it is proposed to classify Google services for the purposes of scientific and pedagogical work of teachers of educational institutions on the following grounds: general services; services for self-organization and productivity; services for educational purposes; services for scientific purposes; services for commercial and other purposes. It is established that in order to increase the efficiency of different goals, it is advisable to combine Google services for different purposes, such as general, educational and to increase productivity. It has also been established that the collaboration with Google services is organized at the excellent level necessary to work with documents and quickly access the information, taking into account the current conditions of the pandemic. The analysis of the directions of education reform and the possibilities of application of information technologies during their implementation gives grounds to assert that the decisive factor in achieving the main goals of education reform is its informatization. And the use of modern information technologies and services helps to increase the self-organization and productivity of the administration of the educational institution, teachers and students, to optimize educational and management processes. The results of the study are the basis for further research in terms of more effective use of modern information technology and services in public institutions on the example of educational institutions.
\end{abstract}

Keywords: information technologies, information services, public institutions, educational institutions, Google services.

JEL Classification: M15, I20. 


\section{INTRODUCTION}

The current stage of informatization of society is flourishing and rising, it is characterized by rapid changes in conceptual positions on the role, methods, and techniques in the training of future professionals, as well as the emergence of the pandemic, which necessitated distance learning and work. Therefore, today information technology is the most popular means to qualitatively improve the intellectual and educational level of people. Thus, the use of electronic means can increase the efficiency and quality of learning material; it opens up great opportunities for improving the learning process by changing the level of its individualization and differentiation, promotes the organization of personalityoriented learning.

The national doctrine of education development in the XXI century states that the priority of education development is the introduction of modern information technologies that provide access to a network of high-quality databases, expand opportunities for the perception of complex information. This is done by building individual training programs of different levels of complexity, depending on specific needs, the use of the Internet, the introduction of distance learning, the publication of electronic textbooks.

One of the main goals of the development of the information society in Ukraine is to ensure computer and information literacy of the population, primarily by creating an education system focused on the use of the latest information technologies in the formation of a fully developed personality.

\section{LITERATURE REVIEW, GENERALIZATION OF MAIN STATEMENTS}

For the information support of the educational process, every pedagogical worker and student must have constant access to an unlimited amount of information and its analytical processing, the ability to directly interact with the information culture of society.

Computer-based learning technologies are aimed at fulfilling the tasks of informatization of education based on the use of a set of functionally dependent pedagogical, methodological, psychophysiological, informational, and ergonomic tools and techniques that have been created and organized on the basis of hardware and software.

Specialists identify several basic areas of use of information technology in the educational process [1, p.12]:

- for a visual demonstration of the basic concepts and objects of the subject, the basic laws, the connection of theoretical knowledge with practice, etc.;

- for modeling and visual representation of physical processes occurring in the studied technical devices, the functioning of the studied samples;

- for automated learning;

- for design automation;

- to solve computational problems, processing the results of measurements of experimental studies;

- to control the readiness of students.

Research on the application of information technology in the work of educational institutions in modern conditions involves the following scientists.

D. Benito-Osorio, M. Peris-Ortiz, C. Rueda Armengot, A. Colino investigated the future of emotional competences in higher education. The European Higher Education Area has adapted to ICT, proposing a conceptual and methodological change in teaching-learning processes in Spanish universities. In this new scenario, the education of students via the Web has become a key factor that requires higher education teachers to have new emotional competences. Although affections, feelings and emotions have been gaining relevance in society and scientific thought for more than a decade now, in the future, we will be dealing with a sensory emotive Web (Web 5.0) and, more than ever 
before, there will be a deep need for teachers to use and promote intra- and interpersonal emotional competences [2, p. 275].

K. Kró investigated the evolution of online mapping: from Web 1.0 to Web 6.0. In particular, Web 5.0 performance appears limited only if seen through the prism of technological development. It presents the web as a human-controlled tool, which uses algorithms to attempt to personalize, search, and improve user experience, and to act for or on behalf of a person. Meanwhile, in the Web 6.0 era, the world will be quite unlike what we know today. For instance, it may turn out that Web 6.0 will mean the migration of human consciousness to cyberspace or to an unspecified "cloud" (of data, perhaps?). Will online maps even be needed in such a world? The Web, seen in its current way, is "anchored in metabolism". Web 6.0 endeavours to face up to that [3, p. 33]. A similar study was conducted on Web 5.0 Strategy by A. Kambil [4, p. 57]. Such technologies include the use of the latest Google services. I.D. Piatnychuk in her work [5] researched the application of software for public joint stock companies.

The need and principles of implementation of information and communication infrastructure to ensure the effective operation of the educational institution were researched by O.B. Bilyk [6, p. 127]. N.V. Vakulenchyk also studied information support for the management of educational institutions [7, p. 49]. L. Vysotska devoted her scientific work to the creation of an information and educational environment in vocational education institutions [8, p. 116]. And S.L. Londar's monograph devoted to development of information systems of management of education as the tool of realization of the state educational policy [9]. The informatization of organizational and managerial activities in secondary school was researched O.E. Kravchina [10]. Thus, the above list of studies indicates the relevance of the chosen topic and the need to deepen the study.

\section{Discussion}

Computer-based learning technology is a tool that allows teachers to qualitatively change the methods and organizational forms of their work and on this basis to develop individual abilities of students, to encourage everyone to harmonize their inherent personal qualities; focus on the formation of cognitive abilities, on effective learning activities; support and develop the desire for selfimprovement; to strengthen interdisciplinary connections in education, the complexity of the study of the phenomena of reality, to ensure the inseparable links between science and technology, the humanities and the arts; to carry out constant dynamic updating of educational process, its forms and methods, to provide debureaucratization of educational institutions, their constant adaptation to changing external conditions and a contingent of pupils, etc. [11, p. 40].

Software development is an important component of computerization of learning. Programs used in educational institutions are subject to [12, p. 33]:

- educational (direct learning based on existing knowledge and individual abilities of students, as well as promote the assimilation of new information);

- diagnostic (test) (designed to diagnose, test, assess knowledge, skills, abilities); training (designed to repeat the consolidation of the completed training material);

- databases (repositories of information from different fields of knowledge, in which with the help of search queries in different areas of knowledge find the necessary information);

- imitation (represent a certain aspect of reality with the help of parameters to study its basic structural or functional characteristics);

- modeling (reflect the basic elements and types of functions, model a certain reality);

- programs such as "microworld" (similar to simulation, but do not reflect reality, but create a virtual learning environment);

- software tools (provide specific operations, i.e. word processing, compiling tables, editing graphic information).

The introduction of information technology in the educational process is accompanied by an increase in the volume of independent work of students, which requires constant support of the educational process by teachers. An important role belongs to consultations, which are complicated in 
terms of didactic goals: they are preserved as independent forms of organization of the educational process and at the same time are elements of other forms of educational activities.

With the use of information technology, the possibilities of organizing independent work of students are expanding. Independent work with research and educational literature on paper remains as an important part of independent work of students in general, but its basis is now independent work with curricula, testing systems, information databases.

The effectiveness of the use of information technology in the educational process depends on the success of solving problems of a methodological nature related to the information content and the method of using automated learning systems. Therefore, automated learning systems should be considered as software and methodological complexes (a set of software and hardware and implemented with their use of teaching methods (techniques), designed to solve specific problems of the educational process).

At the present stage of social and technological transformations, one of the requirements for all participants in the educational process in educational institutions is the readiness of the future specialist to use information and communication technologies, computerized systems in general in education and professional activities. There are three levels of such readiness: own level of mastery of computer technology, the ability to directly use them in professional activities, the ability to improve their professional level through the Internet. An important element of this readiness is not only theoretical training in a particular field of knowledge, but also the practical skills of the teacher to organize and conduct classes with the help of computer tools and technologies; to prepare a training session for distance learning; apply proprietary development of electronic textbooks; create your own e-textbook on a specific discipline; to introduce an educational Web-site in order to deepen their own scientific and teaching competence [13, p. 34].

For effective use of modern information and communication technologies in the educational process, the teacher must have certain specific skills:

- apply modern information and communication technologies in the preparation, analysis, adjustment of the educational process, management of the educational process and educational and cognitive activities of students;

- choose the most rational methods and means of teaching, take into account the individual characteristics of students, their inclinations and abilities;

- effectively combine traditional methodological systems of education with new information and communication technologies.

The introduction of new information technologies into the educational process in higher education is an objective process of educational development. However, they should not be used by teachers thoughtlessly, because none of the technologies can be considered universal: each of them in different situations gives different results, and this must be taken into account when choosing them.

Google commissioned Forrester Consulting to conduct a Total Economic Impact ${ }^{\mathrm{TM}}$ (TEI) study and examine the potential return on investment (ROI) enterprises may realize by deploying Google Workspace. The purpose of this study is to provide readers with a framework to evaluate the potential financial impact of Google Workspace on their organizations. Google Workspace offers a set of work applications that help organizations transform their. To better understand the benefits, costs, and risks associated with this investment, Forrester interviewed eight enterprise customers with years of experience using Google Workspace [14, p. 1].

Interviewed organizations noted that the migration to Google Workspace transformed the way their employees worked. Google Workspace enabled better collaboration across teams, gave workers better access to data to inform decision making, and sparked a cultural change toward embracing innovation. Organizations reported upticks in internal, employee-led initiatives that accelerated the business and ultimately had a positive impact to their bottom lines.

Forrester's interviews with eight existing Google Workspace customers, and the subsequent financial analysis, found that a composite organization experienced benefits of $\$ 55.7$ million over three 
years, and costs of $\$ 12.9$ million. This results in a net present value (NPV) of $\$ 42.8$ million and an ROI of $331 \%$ (Fig. 1) [14, p. 3].

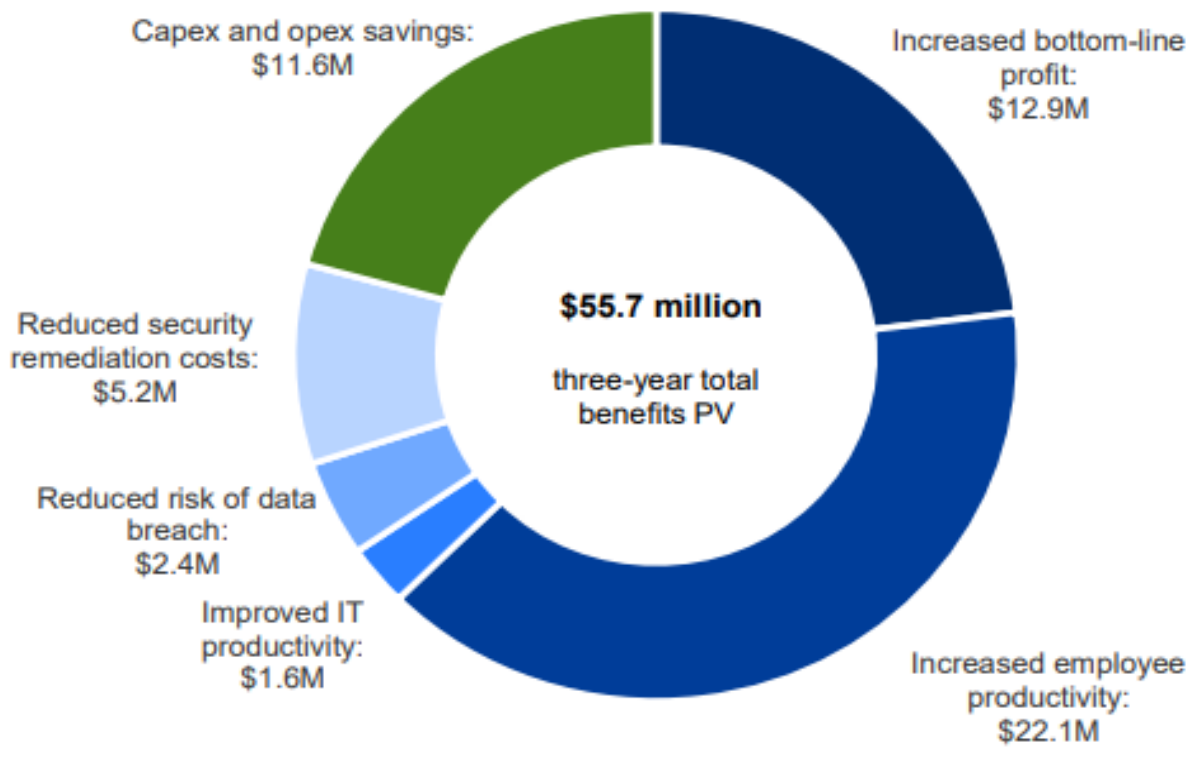

Fig. 1. Benefit Summary using Google Workspace [14, p. 3].

Therefore, it is proven that the use of Google services creates an economic advantage and increase the efficiency of the organization. The use of such services in the work of educational institutions will also have a positive effect.

Google's cloud service is a set of network services that work together for all users in the community. Cloud technology is a paradigm that involves remote processing and storage of data. This technology provides Internet users with access to the server's computer resources and the use of the software as an online service. That is, if you have an Internet connection, you can perform complex calculations, process data using the power of a remote server.

Necessary components for work in "clouds":

- Internet;

- Computer (tablet, mobile phone, laptop);

- Browser;

- A company that provides cloud technology services;

- Internet and web application skills.

Advantages of use:

- No need for powerful computers;

- Less costs for the purchase of software and its systematic updating;

- Unlimited data storage;

- Availability from various devices and no connection to the workplace;

- Ensuring data protection against losses and the implementation of many types of educational activities, monitoring and evaluation, online testing, open educational environment;

- Saving money on the maintenance of technical specialists.

Cloud technology is an electronic data warehouse on the Internet that allows you to store, edit, and share information with friends and colleagues. Technologies were first discussed in 2008. Cloud technology includes the browser interface of the mailbox, the ability to create and edit office documents online, and complex mathematical calculations for which the power of one personal computer is not enough. In short, cloud technologies are data processing technologies in which computer resources are provided to an Internet user as an online service.

Compared to the traditional approach, cloud services allow you to manage large infrastructures, serve different user groups within a single cloud, and also mean complete dependence on a cloud 
service provider. The user of cloud services needs to worry about the infrastructure that ensures the efficiency of the services provided to him.

Thus, the compilers of cloud technologies in education can be e-journals, journals, features of classrooms for students and teachers, interactive engagements, thematic training forums for students.

Involvement of the "Google" service allows to solve problems of information support of daily management, joint editing of documents, storage and informing of the information which is transferred from the user to the user.

Google services are gaining popularity among teachers who actively help services in their pedagogical activities (Fig. 2) [15].

\section{Включені додатки}

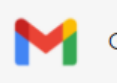

Gmail

D Docs

$\infty$

Currents

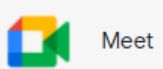

田 Sheets

Keep

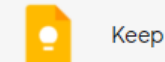

Keep

Endpoint

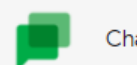

Slides

Apps Script

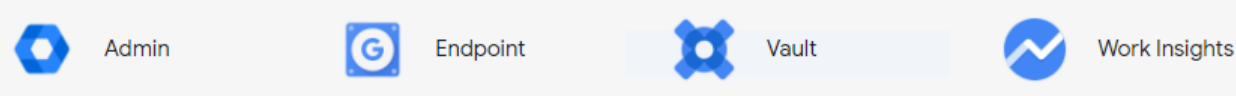

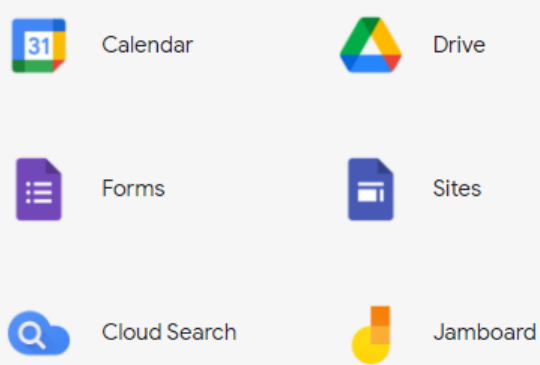

Безпека й керування

Fig. 2. Popular Google services [15].

Consider the user services of "Google" and try to identify those that can be used in the administrative work of the head of the educational institution.

Based on the practical use of "Google" services, they are grouped for the purposes of scientific and pedagogical work of teachers of educational institutions:

1) General Services: Google Search, Google News, Google Images, YouTube, Google Translate, Gmail, Google Drive, Google Maps, Google Docs, Google Sheets, Google Presentations, Google Forms, Google Images, Blogger.

2) For self-organization and productivity: Google Calendar, Gmail, Google Tasks, Google Keep, Google Groups, Google Meet, Google Chat, Google Duo, Google Travel.

3) For educational purposes: Google Classroom, Google Blogger, Google Jamboard, Google Podcasts, Google Meet, Google Groups.

4) For scientific purposes: Google Public Data Explorer, Google Trends, Google Scholar.

5) For commercial and other purposes: Google My Business, Google Sites, Google Analytics, Google Ads, Google Trends.

It should be noted that to increase the efficiency of various purposes, it is advisable to combine Google service for different purposes, such as general, educational and to increase productivity.

Collaboration with documents in "Google" is organized at a high level, sufficient to work with documents and quickly and efficiently access general information.

With Google Drive, the head of the school and other users (employees) can work together in real time, for example on documents, reports or projects. 
Google Drive provides ample opportunities to collaborate on documents. In order to make working with documents as convenient and productive as possible for a group of employees, the following options are available:

Document version management: intermediate versions of the document are created by the system automatically quite often and, moreover, every time the user saves the document. The function of comparison of two selected versions is available that allows to trace easily the changes which have been brought by the next editing of the document [15].

Document access control:

- you can invite system users to work with the document, indicating what rights are given to the user: only view the document or edit;

- additional features allow the user who was asked to work with the document, in turn, to invite other users;

- people who work with the document at the same time can arrange a chat to discuss changes in the document, which will be visible to all participants in the discussion [15].

It is possible to publish a document with a permanent address, which allows any authorized employee to access the document (for example, after all changes have been made and approved, the document is published for public review).

Google Drive integrates perfectly with Google Calendar, which is used at the school for current and future work planning. Key features and capabilities of Google Calendar:

- create one or more thematic calendars (for example, "Grants", "Orders", etc.).;

- the created calendar or a separate event can be accessed by all school employees or only a separate group from the corporate database of e-mail addresses;

- link files from Google Drive to a single event;

- there are reminders of events;

- it is possible to import calendars from other programs [15].

Also added the ability to track time statistics, including time spent in meetings, which allows you to analyze your performance.

Because GSuite for Edu includes most of the services provided by Google, educators have the ability to easily collaborate with documents using Google Docs, maintain their own employment calendars, plan joint activities (as part of the Calendar service), synchronize data between computers (at work and at home) with the help of "Google Drive", to record tasks, notes, robot with chat and myth [15].

The transition to the use of corporate mail has allowed to scale the unified information system (UIS), based on which it is easy to implement new tools to optimize performance. According to the requirements, the system is implemented in stages.

The implementation of UIS is reflected directly in the educational process: each teacher received his account to enter the "Google Classroom", where he can provide additional materials on their subjects, test knowledge, test students' tasks and more. Teachers have independently mastered the tool provided to them in those areas that are most important to them - create thematic blogs, work collectively on documents [15].

The creation and implementation of the UIS process is quite long, but the advantages of a single system are manifested at each stage of implementation. Employees of educational institutions daily learn new ways to use different tools in their pedagogical work.

\section{CONCLUSIONS}

So, of course, the requirements for education have changed: in addition to basic knowledge and constant mastery of new, modern worker must be able to productively use information resources. Today he is required to be able to think creatively, make decisions and learn throughout life. Nowadays, there are often demands to improve the training of a new generation of employees, which is reflected in the implementation of many government programs, as well as projects implemented by 
commercial organizations and charitable foundations. However, this is not enough - it is necessary to redouble efforts to improve education.

The analysis of the directions of education reform and the possibilities of application of information technologies during their implementation, gives grounds to assert that the decisive factor in achieving the main goals of education reform is its informatization. And the use of modern information technologies and services help to increase the self-organization and productivity of the administration of the educational institution, teachers and students, to optimize educational and management processes. Effective systems of informatization of education can be created if they are based on the study of activities carried out in the education system, and take into account both the current state and possible transformations of education in the process of its reform, the current state and prospects of information technology, psychology and information technology training.

To successfully solve the problems of informatization of education in Ukraine, it is advisable to conduct comprehensive research in the above areas with broad involvement in the implementation of this work of scientific institutions of the Academy of Pedagogical Sciences of Ukraine, universities.

\section{REFERENCES}

[1] Petlyushenko N.I. Introduction of computer technologies in school. Primary education and upbringing, $\mathbf{1}$ (2012), 12-13. (in Ukrainian)

[2] Benito-Osorio D., Peris-Ortiz M., Rueda Armengot C., Colino A. Web 5.0: the future of emotional competences in higher education. Global Business Perspectives, 1 (2013), 274-287.

[3] Król K. Evolution of online mapping: from Web 1.0 to Web 6.0. Geomatics, Landmanagement and Landscape, 1 (2020), 33-51.

[4] Kambil A. What is your Web 5.0 Strategy? Journal of Business Strategy, 29 (2008), 56-58.

[5] Piatnychuk I.D. Organization of management cost accounting in terms of application of budgeting system software. Effective economics, 12 (2012). Available at: http://www.economy.nayka.com.ua. (in Ukrainian)

[6] Bilyk O.B. The need and principles of implementation of information and communication infrastructure to ensure the effective operation of educational institutions. Bulletin of the Khmelnytsky National University, 1 (2011), 127-132. (in Ukrainian)

[7] Vakulenchyk N.V., Rozhnova T. Information support of educational institutions management. Proceedings of the All-Ukrainian scientific-practical conference "Scientific approaches in the management of educational institutions", 2015, 49-54. (in Ukrainian)

[8] Vysotska L. Creation of information and educational environment in vocational education institutions in the field of service. Scientific Bulletin of the Institute of Vocational Education of the National Academy of Pedagogical Sciences of Ukraine, 15 (2018), 116-123. (in Ukrainian)

[9] Londara S.L. Development of information systems of education management as an instrument of realization of the state educational policy. DNU "Institute of Educational Analytics". Kiev, 2020. (in Ukrainian)

[10] Kravchina O.E. Informatization organization and management activities in secondary schools. Information technologies and learning tools, 7 (3) (2008) (in Ukrainian)

[11] Popkova O.P. The use of Internet technologies, social networks in primary school. Computer at school and family, 3 (2012), 40-42. (in Ukrainian)

[12] Ocheretyana O. Formation of subject competencies by means of ICT. Primary education, 33 (2012), 33-35. (in Ukrainian)

[13] Rakov S.A. Problems of information education in Ukraine. Computer at school and family, 2 (2010), 34-35. (in Ukrainian)

[14] The Total Economic Impact ${ }^{\mathrm{TM}}$ Of Google Workspace. Business Benefits And Cost Savings Enabled By Google Workspace - Everything you need to get work done in one place. A Forrester Total Economic Impact $^{\mathrm{TM}}$ Study Commissioned By Google. 2019 
[15] Work even more productively in a single environment. Google Workspace. Available at: https://workspace.google.com/intl/uk/features/. (in Ukrainian)

Address: Iryna Piatnychuk, Halyna Pyatnychuk, Vasyl Stefanyk Precarpathian National University, 57, Shevchenko Str., Ivano-Frankivsk, 76018, Ukraine.

E-mail: iryna.piatnychuk@pnu.edu.ua, halyna.piatnychuk@pnu.edu.ua.

Received: April 16, 2021; revised: June 10, 2021.

П'ятничук Ірина, П'ятничук Галина. Сучасні інформаційні технології та сервіси в публічних інституціях. Журнал Прикарпатського університету імені Василя Стефаника, 8 (3) (2021), 43-51.

У статті розглянуто питання сучасних інформаційних технологій та сервісів в публічних інституціях (на прикдаді закладів освіти). Метою статті є дослідження питання застосування сучасних інформаційних технологій та сервісів, зокрема сервісів Google, в таких публічних інституціях як закдади освіти у сучасних умовах пандеміі та виявлення мождивостей їх більш ширшого використання. 3 урахуванням дослідження щодо оцінки отримання економічних вигод від використання сервісів Google, встановлено, що їх більш ширше застосування у закладах освіти матиме також позитивний ефект. Визначено, що використання сервісу "Google" дозволяє вирішувати проблеми інформаційного супроводу управлінських та освітніх процесів у закладі освіти, спільного працювати над різними типами документів, уникнення спотворення інформації в ході роботи над ними різними користувачами 3 допомогою встановлення відповідного рівня доступу до документу. На основі проведеного дослідження запропоновано класифікувати сервіси Google для цілей науковопедагогічної роботи викдадачів закладів освіти за наступними ознаками: загальні сервіси; сервіси для самоорганізації та підвищення продуктивності; сервіси для навчальних цілей; сервіси для наукових цілей; сервіси для реалізації комерційних та інших цілей. Встановлено, що для підвищення ефективності реалізації різних цілей доцільно поєднувати між собою Google сервіси різного призначення, наприклад загальні, навчальні і для підвищення продуктивності. Також встановлено, що спільна робота з сервісами Google організована на відмінному рівні, необхідному для того, щоб працювати із документами й оперативно отримувати доступ до потрібної інформації з урахуванням сучасних умов пандемії. Аналіз напрямків реформування освіти і можливостей застосування інформаційних технологій під час їх здійснення, дає підстави стверджувати, що вирішальним чинником досягнення основних цілей реформування освіти є іï інформатизація. I застосування сучасних інформаційних технологій та сервісів сприяють підвищенню самоорганізації та продуктивності адміністрації закладу освіти, викладачів та здобувачів освіти, здійснювати оптимізацію освітніх та управлінських процесів. Отримані результати проведеного дослідження виступають основою для наступних досліджень у частині більш ефективного використання сучасних інформаційних технологій та сервісів у публічних інституціях на прикладі закладів освіти.

Ключові слова: інформаційні технології, інформаційні сервіси, публічні інституції, навчальні заклади, сервіси Google. 